\title{
The Effect of Accupressure on Hyperemesis Gravidarum and Birth Delivery Pain in Pregnant Women: A Meta Analysis
}

\author{
Alfira Fitriana1), Agus Kristiyanto'), Hanung Prasetya3) \\ 1)Masters Program in Public Health, Universitas Sebelas Maret \\ 2)Faculty of Sport Education, Universitas Sebelas Maret \\ ${ }^{3}$ Health Polytechnics, Ministry of Health Surakarta
}

Background: Nausea and vomiting in pregnancy is a common condition experienced by $50-80 \%$ of pregnant women between 6 to 12 weeks of pregnancy. Acupressure stimulation can stimulate and increase blood circulation and vital energy, so as to maintain normal body functions. The purpose of this study was to determine the effect of acupressure on hyperemesis gravidarum and labor pain in pregnant and childbirth women.

Subjects and Method: This was a metaanalysis and systematic study. The articles used were obtained from PubMed, Science Direct and Google Scholar. The inclusion criteria used were full text articles with Randomized Control Trial (RCT) design. Research subjects are pregnant women or giving birth. The intervention given was acupressure with the comparison not being given acupressure or fake acupressure, articles published in English and Indonesian. The PICO research problems were as follows: Population $=$ pregnant women and childbirth, Intervention= giving acupressure, Comparison $=$ sham acupressure or without acupressure, Outcome $=$ reduced intensity of nausea and vomiting and labor pain. The study was conducted using an effect size (Standardized Mean Difference). Meta-analysis was carried out using RevMan 5.3 with a random effect model.
Results: A total of 20 articles were reviewed in a meta-analysis in this study. Meta-analysis of 9 articles showed acupressure was effective in reducing hyperemesis gravidarum. Pregnant women who received acupressure therapy experienced hyperemesis gravidarum 0.8 units lower than those without acupressure $(\mathrm{SMD}=-$ 0.84 ; $95 \% \mathrm{CI}=-1.18$ to -0.5 ; $\mathrm{p}<0.001)$. A metaanalysis of 11 articles showed that acupressure was effective in reducing labor pain. Pregnant women who received acupressure therapy experienced labor pain 1.8 units lower than without acupressure $(\mathrm{SMD}=-1.83 ; 95 \% \mathrm{CI}=-$ 2.37 to $-1.29 ; \mathrm{p}<0.001$ ).

Conclusion: Acupressure can reduce the intensity of nausea and vomiting in pregnant women who experience hyperemesis gravidarum as well as the intensity of labor pain in pregnant women.

Keywords: Acupressure, hyperemesis gravidarum, labor pain, meta analysis

\section{Correspondence:}

Alfira Fitriana. Masters Program in Public Health. Universitas Sebelas Maret, Jl.Ir. Sutami 36A, Surakarta 57126, Central Java, Indonesia. Email: firafitrianao1@gmail.com. Mobile: 085812071211.

Cite this as:

Fitriana A, Kristiyanto A, Prasetya H (2021). The Effect of Accupressure on Hyperemesis Gravidarum and Birth Delivery Pain in Pregnant Women: A Meta Analysis. 06(03): 365-375. https://doi.org/10.26911/thejmch.2021.06.03.11.

cc) (†) (9) Journal of Maternal and Child Health is licensed under a Creative Commons Attribution-NonCommercial-ShareAlike 4.o International License.

\section{BACKGROUND}

Nausea and vomiting in pregnancy is a common condition experienced by $50-80 \%$ of pregnant women between 6 to 12 weeks of pregnancy (Mobarakabadi et al., 2019). If nausea and vomiting occur continuously, and result in weight loss of more than $5 \%$, ketones in the urine, and dehydration 
confirmed by an increase in urine specific gravity then it is a sign of hyperemesis gravidarum (Tulmac et al., 2021). Hyperemesis gravidarum is reported to have occurred in $0.3-10.8 \%$ of pregnant women or about 1 in 200 pregnant women experience it and can cause complications such as premature birth, Wernicke's encephalopathy, liver and kidney damage (Martonffy et al., 2012).

The pain of labor will be felt by the mother when the child is born. The pain caused is subjective and complex and involves physiological, cultural and psychosocial aspects (Mafetoni and Shimo, 2016).

Labor pain is an unpleasant sensation due to personal sensory nerve stimulation, because everyone perceives pain differently to the same stimulus depending on the pain threshold they have (Alam, 2020). Labor pain is a physiological process and will end with the birth of a baby, realistic preparation and knowledge of the labor process helps coping skills with labor pain (Setyowati, 2018). Negative effects also have on the physiological status of the mother and fetus and the progress of labor, including increased oxygen demand, increased pulmonary ventilation, increased heart rate, delayed gastric emptying, inefficiency of uterine contractions, prolonged labor, decreased uterine perfusion, fetal hypoxia and metabolic acidosis. It results in maternal anxiety and discomfort during the delivery process.

Although there are various types of non-pharmacological measures available to relieve nausea and vomiting and labor pain, acupressure is safe, inexpensive and effective to help reduce nausea and vomiting and labor pain and improve pain management (Hamidzadeh et al., 2012).

Acupressure is a technique that creates a balance of energy or known as qi in the body. Stimulation of acupressure points can stimulate and increase blood circulation and vital energy, harmony between yin and yang and neurotransmitters so as to maintain normal body functions and create comfort in the body (Mahmoudikohani et al., 2019).

Bulbul and Baser (2018) reported that acupressure applied to PC6 acupuncture points with a bracelet does not completely eliminate nausea and or vomiting caused by hyperemesis gravidarum but has a decreasing effect over certain periods of the day.

A randomized controlled trial by Ozgoli et al., (2016), showed the reduction of labor pain significantly greater in the $\mathrm{Li} 4$ and BL32 acupressure groups compared to the control group in all study periods.

This study is expected to prove the effect of giving acupressure to reduce the intensity of nausea and vomiting in pregnant women who experience hyperemesis gravidarum and the intensity of labor pain in laboring women analyzed from various existing primary studies.

\section{SUBJECTS AND METHOD}

\section{Study Design}

This was a systematic review and metaanalysis with PRISMA flow diagram. Article searches were performed using the following databases: PubMed, Science Direct, and Google Scholar. Some of the keywords used: accupressure OR pressure OR "accupuncture point" AND "hyperemesis gravidarum" OR nausea OR vomiting AND "labor pain" AND "randomized controlled trial".

\section{Inclusion Criteria}

The inclusion criteria used were full text articles with Randomized Control Trial (RCT). The study subjects are pregnant women. The intervention is acupressure with comparison not given acupressure or sham acupressure, and articles published in English and Indonesian. 
Fitriana et al./ Accupressure on Hyperemesis Gravidarum and Birth Delivery Pain

\section{Exclusion Criteria}

The exclusion criteria for this research article were that the results of the study did not include the complete mean and standard deviation, the treatment given was acupressure with other additional treatments.

\section{Operational Definition of Variables}

Articles included in the study were PICOadjusted. The search for articles was carried out by considering the eligibility criteria defined using the PICO model. Population= Pregnant women and giving birth, Intervention $=$ Giving acupressure, Comparison= Fake acupressure or without acupressure, Outcome $=$ intensity of nausea, vomiting and labor pain is reduced.

Acupressure is the application of manual pressure with fingers or tools at certain acupuncture points for 3-5 minutes or 5 times each contraction for 20-30 minutes measured using a stopwatch with a dichotomous measurement scale.

Hyperemesis gravidarum is the amount of decrease in the intensity of nausea and vomiting after treatment with acupressure, PUQE (Pregnancy-Unique Quantification of
Emesis and Nausea) measurement instrument, Rhodes Index of nausea and vomiting and retching form with continuous measurement scale.

Labor Pain is the number of reductions in pain intensity after acupressure treatment, measurement instrument VAS (Visual Analogue Scale), Faces Pain Rating Scale, with a continuous measurement scale.

\section{Instrument}

The study was conducted using the PRISMA flow diagram guidelines and the assessment of the quality of the research articles was carried out using the Critical Appraisal Checklist for RCT Study tools (CEBM, 2014).

\section{Data Analysis}

The data in this study were analyzed using the RevMan 5.3 application, to calculate the effect size and heterogeneity of the study. The results of data processing are presented in the form of forest plots and funnel plots.

\section{RESULTS}

The article review process using the PRISMA flow diagram can be seen in Figure 1.

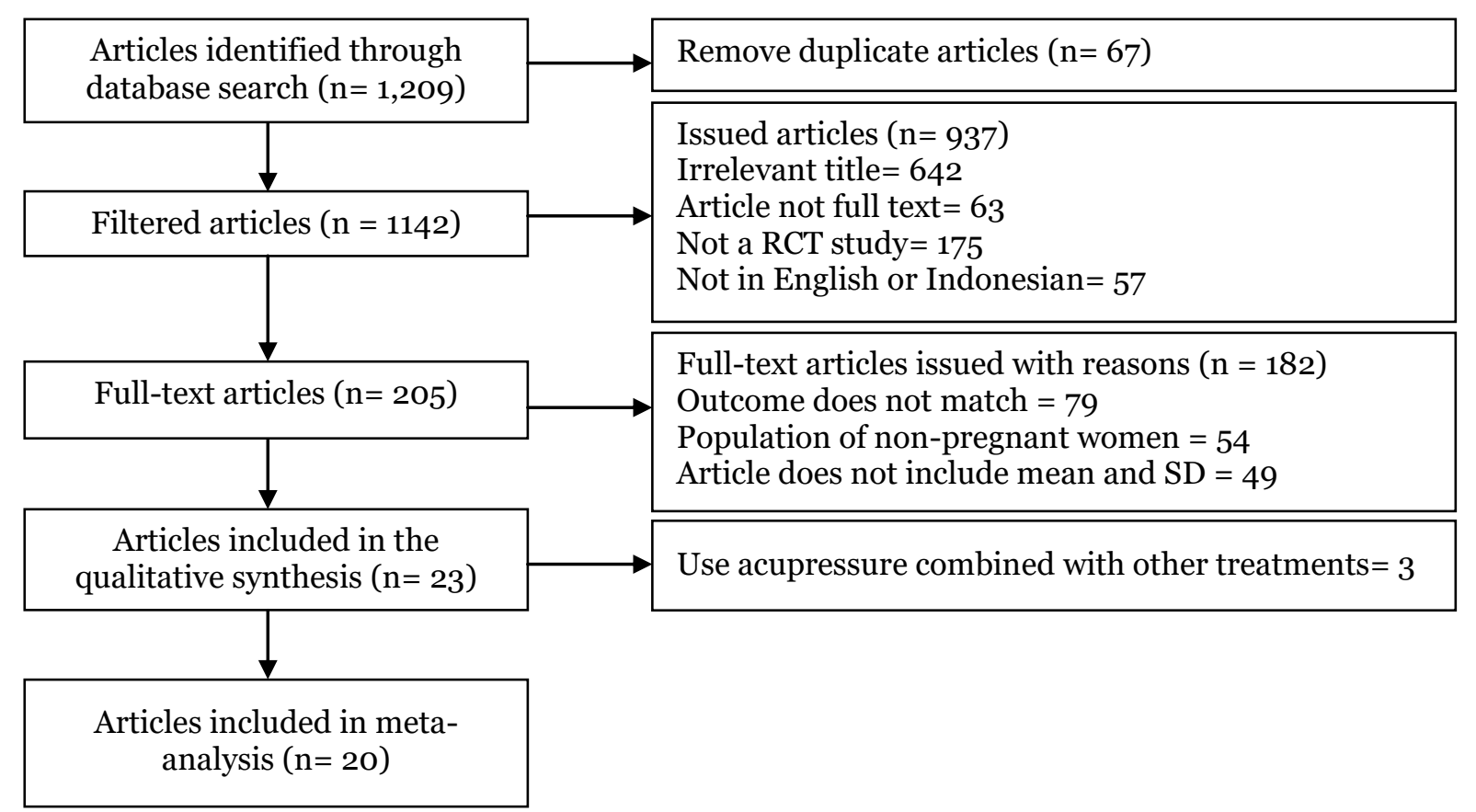

Figure 1. PRISMA flow diagram 
Figure 1 showed the total articles were 20 articles (19 from Asia and 1 from South America).

1. Effect of acupressure on hyperemesis gravidarum

Table 1. Effect of acupressure on hyperemesis gravidarum in pregnant women

\begin{tabular}{|c|c|c|c|c|c|c|c|}
\hline \multirow{3}{*}{\begin{tabular}{l}
\multicolumn{1}{c}{$\begin{array}{c}\text { Author, } \\
\text { Year }\end{array}$} \\
Adlan et al., \\
2017
\end{tabular}} & \multirow{3}{*}{$\begin{array}{c}\text { Country } \\
\text { Malaysia }\end{array}$} & \multirow{3}{*}{$\begin{array}{l}\begin{array}{c}\text { Popula- } \\
\text { tion }\end{array} \\
\text { pregnant } \\
\text { women } \\
5^{-14} \\
\text { weeks }\end{array}$} & \multirow{3}{*}{$\begin{array}{c}\begin{array}{c}\text { Instru- } \\
\text { ment }\end{array} \\
\text { PUQE }\end{array}$} & \multicolumn{4}{|c|}{ Result } \\
\hline & & & & \multicolumn{2}{|c|}{ Intervention } & \multicolumn{2}{|c|}{ Comparison } \\
\hline & & & & Acupressure & $\begin{array}{l}\text { Mean : } 2.87 \\
\text { SD : } 1.19\end{array}$ & $\begin{array}{l}\text { Sham } \\
\text { acupress } \\
\text { ure }\end{array}$ & $\begin{array}{l}\text { Mean : } \\
3.18 \\
\text { SD : } 1.41\end{array}$ \\
\hline $\begin{array}{l}\text { Aghdam and } \\
\text { Kazemzadeh } \\
2013\end{array}$ & Iran & $\begin{array}{l}\text { pregnant } \\
\text { women } \\
\text { 10-16 } \\
\text { weeks }\end{array}$ & $\begin{array}{l}\text { Rhodex } \\
\text { Index } \\
\text { score }\end{array}$ & Acupressure & $\begin{array}{l}\text { Mean : } 3.8 \\
\text { SD : } 1.58\end{array}$ & $\begin{array}{l}\text { Sham } \\
\text { acupress } \\
\text { ure }\end{array}$ & $\begin{array}{l}\text { Mean : } 5.5 \\
\text { SD : } 2.03\end{array}$ \\
\hline $\begin{array}{l}\text { Djanah } \\
\text { (2014) }\end{array}$ & $\begin{array}{l}\text { Indo- } \\
\text { nesia }\end{array}$ & $\begin{array}{l}\text { pregnant } \\
\text { women< } \\
16 \text { weeks }\end{array}$ & PUQE & Acupressure & $\begin{array}{l}\text { Mean : } 4.53 \\
\text { SD :1.23 }\end{array}$ & $\begin{array}{l}\text { Sham } \\
\text { acupress } \\
\text { ure }\end{array}$ & $\begin{array}{l}\text { Mean : } \\
6.21 \\
\text { SD : } 2.08\end{array}$ \\
\hline $\begin{array}{l}\text { Ghule et al., } \\
\text { (2020) }\end{array}$ & India & $\begin{array}{l}\text { 6-12 } \\
\text { weeks } \\
\text { pregnant }\end{array}$ & $\begin{array}{l}\text { Rhodes } \\
\text { Index } \\
\text { score }\end{array}$ & Acupressure & $\begin{array}{l}\text { Mean : } 12.29 \\
\text { SD : } 3.07\end{array}$ & $\begin{array}{l}\text { Sham } \\
\text { acupress } \\
\text { ure }\end{array}$ & $\begin{array}{l}\text { Mean : } \\
18.61 \\
\text { SD : } 6.28\end{array}$ \\
\hline $\begin{array}{l}\text { Lepcha et al., } \\
(2020)\end{array}$ & India & $\begin{array}{l}8-12 \\
\text { weeks } \\
\text { pregnant }\end{array}$ & $\begin{array}{l}\text { Rhodes } \\
\text { Index } \\
\text { score }\end{array}$ & Acupressure & $\begin{array}{l}\text { Mean : } 2.6 \\
\text { SD : } 2.24\end{array}$ & $\begin{array}{l}\text { Sham } \\
\text { acupress } \\
\text { ure }\end{array}$ & $\begin{array}{l}\text { Mean : } \\
5.82 \\
\text { SD : } 0.9\end{array}$ \\
\hline $\begin{array}{l}\text { Mobara- } \\
\text { kabadi et al., } \\
\text { (2019) }\end{array}$ & Iran & $\begin{array}{l}\text { pregnant } \\
\text { women < } \\
20 \text { weeks }\end{array}$ & PUQE & Acupressure & $\begin{array}{l}\text { Mean : } 6.42 \\
\text { SD : } 4.1\end{array}$ & $\begin{array}{l}\text { no acu- } \\
\text { pressure }\end{array}$ & $\begin{array}{l}\text { Mean : } \\
9.32 \\
\text { SD : } 3.7\end{array}$ \\
\hline $\begin{array}{l}\text { Negarandeh } \\
\text { et al., (2020) }\end{array}$ & Iran & $\begin{array}{l}\text { pregnant } \\
\text { women } \\
6-16 \\
\text { weeks }\end{array}$ & $\begin{array}{l}\text { Rhodes } \\
\text { Index } \\
\text { score }\end{array}$ & Acupressure & $\begin{array}{l}\text { Mean : } 4.33 \\
\text { SD : } 2.38\end{array}$ & $\begin{array}{l}\text { Sham } \\
\text { acupress } \\
\text { ure }\end{array}$ & $\begin{array}{l}\text { Mean : } \\
5.12 \\
\text { SD : } 2.52\end{array}$ \\
\hline $\begin{array}{l}\text { Puangsri- } \\
\text { carern and } \\
\text { Mahasukhon } \\
\text { (2008) }\end{array}$ & Thailand & $\begin{array}{l}\text { pregnant } \\
\text { women } \\
<14 \\
\text { weeks }\end{array}$ & $\begin{array}{l}\text { Rhodes } \\
\text { Index } \\
\text { score }\end{array}$ & Acupressure & $\begin{array}{l}\text { Mean : } 7.7 \\
\text { SD : } 4.9\end{array}$ & $\begin{array}{l}\text { No acu- } \\
\text { pressure }\end{array}$ & $\begin{array}{l}\text { Mean : } \\
11.3 \\
\text { SD : } 9.2\end{array}$ \\
\hline $\begin{array}{l}\text { Saberi et al., } \\
2013\end{array}$ & Iran & $\begin{array}{l}\text { pregnant } \\
\text { women } \\
<16 \\
\text { weeks }\end{array}$ & $\begin{array}{l}\text { Rhodes } \\
\text { Index } \\
\text { score }\end{array}$ & Acupressure & $\begin{array}{l}\text { Mean : } 2.82 \\
\text { SD : } 2.03\end{array}$ & $\begin{array}{l}\text { No acu- } \\
\text { pressure }\end{array}$ & $\begin{array}{l}\text { Mean : } \\
4.65 \\
\text { SD : } 2.01\end{array}$ \\
\hline
\end{tabular}

\section{a. Forest plot}

Figure 2 the results of the analysis show that acupressure is effective in reducing hyperemesis gravidarum. Pregnant women
Table 1 shows 9 RCT articles on the effect of acupressure on hyperemesis gravidarum in pregnant women who meet qualitative and quantitative requirements. who received acupressure therapy experienced hyperemesis gravidarum 0.8 units lower than without acupressure (SMD = $0.84 ; 95 \% \mathrm{CI}=-1.18$ to $-0.5 ; \mathrm{p}<0.001)$. 
Fitriana et al./ Accupressure on Hyperemesis Gravidarum and Birth Delivery Pain

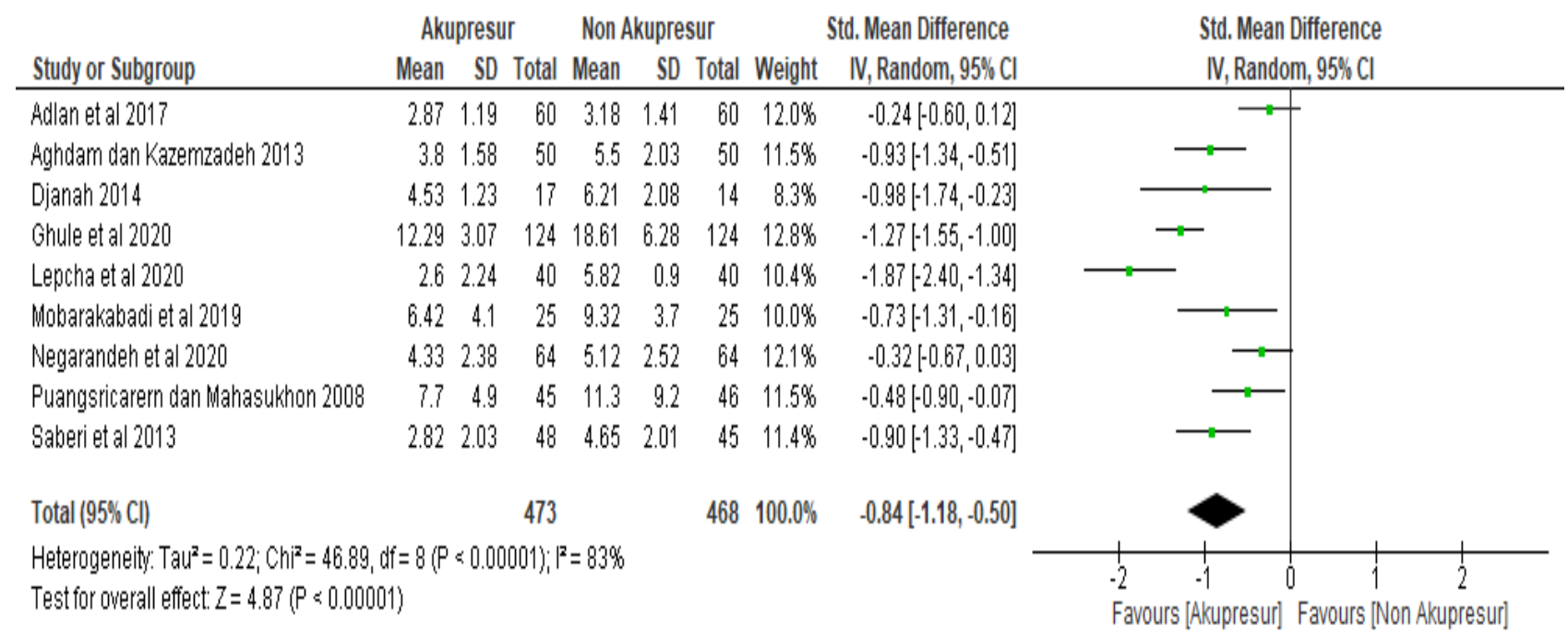

Figure 2. Forest plot of the effect of acupressure on hyperemesis gravidarum in pregnant women

\section{b. Funnel plot}

Figure 3 shows a symmetrical distribution of the primary study estimates to the left and right of the vertical line, indicating that there is no publication bias.

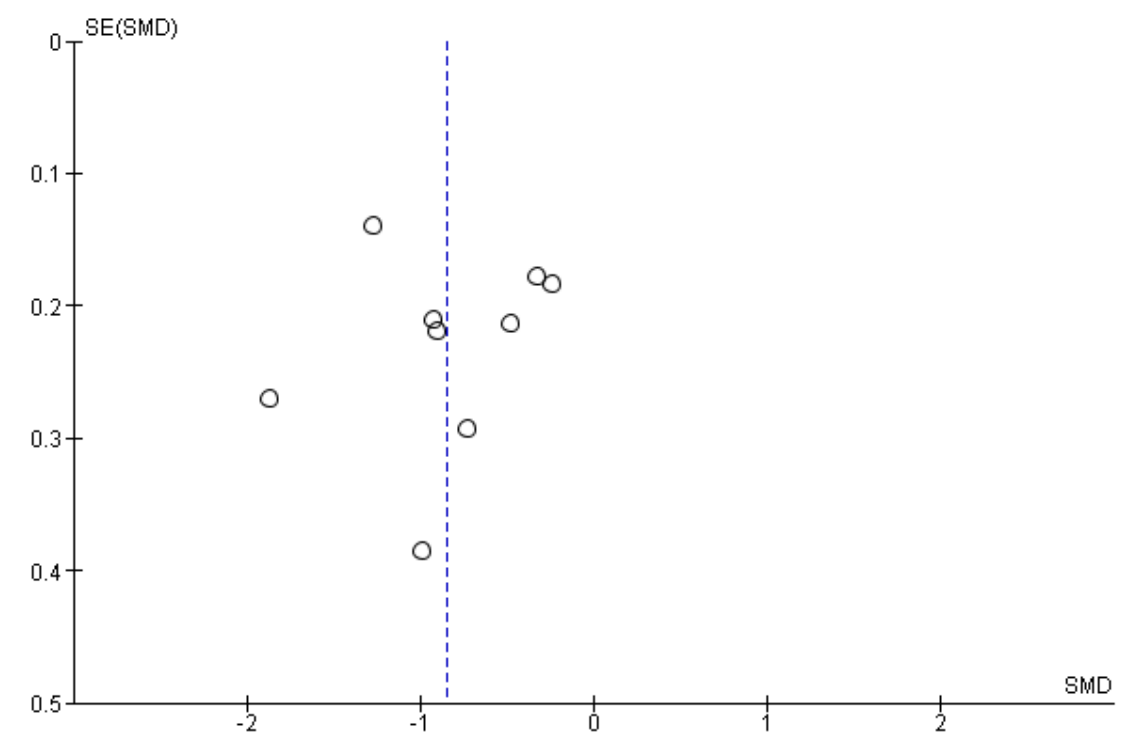

Figure 3. Funnel plot meta-analysis of the effect of acupressure on hyperemesis gravidarum in pregnant women

2. The effect of acupressure on labor pain in laboring mothers.

Table 2 shows 11 randomized control trial (RCT) articles on the effect of acupressure on labor pain in laboring women who meet qualitative and quantitative requirements. 
Fitriana et al./ Accupressure on Hyperemesis Gravidarum and Birth Delivery Pain

Table 2. The effect of acupressure on labor pain in laboring mothers

\begin{tabular}{|c|c|c|c|c|c|c|c|}
\hline \multirow{2}{*}{$\begin{array}{l}\text { Author, } \\
\text { Year }\end{array}$} & \multirow{2}{*}{$\begin{array}{c}\text { Coun- } \\
\text { try }\end{array}$} & \multirow{2}{*}{$\begin{array}{c}\text { Popula- } \\
\text { tion }\end{array}$} & \multirow{2}{*}{$\begin{array}{c}\text { Instru- } \\
\text { ment }\end{array}$} & \multicolumn{4}{|c|}{ Results } \\
\hline & & & & \multicolumn{2}{|c|}{ Intervention } & \multicolumn{2}{|c|}{ Comparisson } \\
\hline $\begin{array}{l}\text { Akbarzadeh } \\
\text { et al., } 2014\end{array}$ & Iran & $\begin{array}{l}\text { Maternity } \\
\text { opening } 3- \\
8\end{array}$ & VAS & $\begin{array}{l}\text { Acupre } \\
\text { ssure }\end{array}$ & $\begin{array}{l}\text { Mean : } 3.44 \\
\text { SD : } 0.907\end{array}$ & $\begin{array}{l}\text { Standard } \\
\text { treatment } \\
\text { without } \\
\text { acupressure }\end{array}$ & $\begin{array}{l}\text { Mean : } 9.4 \\
\text { SD : } 1.01\end{array}$ \\
\hline $\begin{array}{l}\text { Alimoradi et } \\
\text { al., } 2020\end{array}$ & Iran & $\begin{array}{l}\text { Maternity } \\
\text { opening } 3^{-} \\
8\end{array}$ & VAS & $\begin{array}{l}\text { Acupre } \\
\text { ssure }\end{array}$ & $\begin{array}{l}\text { Mean : } 6.86 \\
\text { SD : } 1.24\end{array}$ & $\begin{array}{l}\text { Standard } \\
\text { treatment } \\
\text { without } \\
\text { acupressure }\end{array}$ & $\begin{array}{l}\text { Mean : } 8.56 \\
\text { SD : } 1.24\end{array}$ \\
\hline $\begin{array}{l}\text { Fatimeh et } \\
\text { al., } 2014\end{array}$ & Iran & $\begin{array}{l}\text { Maternity } \\
\text { opening } \\
4-5 \mathrm{~cm}\end{array}$ & VAS & $\begin{array}{l}\text { Acupre } \\
\text { ssure }\end{array}$ & $\begin{array}{l}\text { Mean : } 5.65 \\
\text { SD : } 1.87\end{array}$ & $\begin{array}{l}\text { Standard } \\
\text { treatment } \\
\text { without } \\
\text { acupressure }\end{array}$ & $\begin{array}{l}\text { Mean : } 8.16 \\
\text { SD : } 1.59\end{array}$ \\
\hline $\begin{array}{l}\text { Gonennc \& } \\
\text { Terzioglu } \\
2020\end{array}$ & Turkey & $\begin{array}{l}\text { Maternal } \\
\text { maternity } \\
\text { opening 3- } \\
9 \mathrm{~cm}\end{array}$ & VAS & $\begin{array}{l}\text { Acupre } \\
\text { ssure }\end{array}$ & $\begin{array}{l}\text { Mean : } 7.53 \\
\text { SD : } 1.5\end{array}$ & $\begin{array}{l}\text { Standard } \\
\text { treatment } \\
\text { without } \\
\text { acupressure }\end{array}$ & $\begin{array}{l}\text { Mean : } 9.4 \\
\text { SD : } 0.77\end{array}$ \\
\hline $\begin{array}{l}\text { Hamidzadeh } \\
\text { et al., } 2012\end{array}$ & Iran & $\begin{array}{l}\text { Maternal } \\
\text { maternity } \\
\text { opening> } \\
3 \mathrm{~cm}\end{array}$ & VAS & $\begin{array}{l}\text { Acupre } \\
\text { ssure }\end{array}$ & $\begin{array}{l}\text { Mean : } 6.84 \\
\text { SD : } 0.93\end{array}$ & $\begin{array}{l}\text { Standard } \\
\text { treatment } \\
\text { without } \\
\text { acupressure }\end{array}$ & $\begin{array}{l}\text { Mean : } 8.29 \\
\text { SD : } 1.19\end{array}$ \\
\hline $\begin{array}{l}\text { Hamlaci } \\
\text { \&Yazici } 2017\end{array}$ & Turkey & $\begin{array}{l}\text { Maternal } \\
\text { mother } \\
\text { opening } \\
4-8 \mathrm{~cm}\end{array}$ & VAS & $\begin{array}{l}\text { Acupre } \\
\text { ssure }\end{array}$ & $\begin{array}{l}\text { Mean : } 3.77 \\
\text { SD : } 1.3\end{array}$ & $\begin{array}{l}\text { Standard } \\
\text { treatment } \\
\text { without } \\
\text { acupressure }\end{array}$ & $\begin{array}{l}\text { Mean : } 6.22 \\
\text { SD : } 1.14\end{array}$ \\
\hline $\begin{array}{l}\text { Hjelmstedt } \\
\text { et al., 2010 }\end{array}$ & India & $\begin{array}{l}\text { Maternal } \\
\text { maternity } \\
\text { opening 3- } \\
7 \mathrm{~cm}\end{array}$ & VAS & $\begin{array}{l}\text { Acupre } \\
\text { ssure }\end{array}$ & $\begin{array}{l}\text { Mean : } 74 \\
\text { SD : } 18.2\end{array}$ & $\begin{array}{l}\text { Standard } \\
\text { treatment } \\
\text { without } \\
\text { acupressure }\end{array}$ & $\begin{array}{l}\text { Mean : } 84.3 \\
\text { SD : } 15.8\end{array}$ \\
\hline $\begin{array}{l}\text { Mafetoni \& } \\
\text { Shimo } 2016\end{array}$ & Brazil & $\begin{array}{l}\text { Maternal } \\
\text { maternity } \\
\text { opening> } \\
4 \mathrm{~cm}\end{array}$ & VAS & $\begin{array}{l}\text { Acupre } \\
\text { ssure }\end{array}$ & $\begin{array}{l}\text { Mean : } 5 \cdot 9 \\
\text { SD : } 2.3\end{array}$ & $\begin{array}{l}\text { Standard } \\
\text { treatment } \\
\text { without } \\
\text { acupressure }\end{array}$ & $\begin{array}{l}\text { Mean : } 8.5 \\
\text { SD : } 1.9\end{array}$ \\
\hline $\begin{array}{l}\text { Ozgoli et al., } \\
2016\end{array}$ & Iran & $\begin{array}{l}\text { Maternity } \\
\text { opening } \\
4-10 \mathrm{~cm}\end{array}$ & VAS & $\begin{array}{l}\text { Acupre } \\
\text { ssure }\end{array}$ & $\begin{array}{l}\text { Mean : } 4.49 \\
\text { SD : } 1.65\end{array}$ & $\begin{array}{l}\text { Standard } \\
\text { treatment } \\
\text { without } \\
\text { acupressure }\end{array}$ & $\begin{array}{l}\text { Mean : } 7.09 \\
\text { SD : } 1.26\end{array}$ \\
\hline $\begin{array}{l}\text { Shafaie et } \\
\text { al., } 2013\end{array}$ & Iran & $\begin{array}{l}\text { Maternity } \\
\text { opening } 4 \\
\mathrm{~cm}\end{array}$ & VAS & $\begin{array}{l}\text { Acupre } \\
\text { ssure }\end{array}$ & $\begin{array}{l}\text { Mean : } 4.04 \\
\text { SD : } 1.51\end{array}$ & $\begin{array}{l}\text { Standard } \\
\text { treatment } \\
\text { without } \\
\text { acupressure }\end{array}$ & $\begin{array}{l}\text { Mean : } 6.38 \\
\text { SD : } 1.92\end{array}$ \\
\hline $\begin{array}{l}\text { Torkiyan et } \\
\text { al., } 2021\end{array}$ & Iran & $\begin{array}{l}\text { Maternity } \\
\text { opening } 3\end{array}$ & VAS & CIMT & $\begin{array}{l}\text { Mean : } 6.78 \\
\text { SD : } 1.33\end{array}$ & $\begin{array}{l}\text { Standard } \\
\text { treatment } \\
\text { without } \\
\text { acupressure }\end{array}$ & $\begin{array}{l}\text { Mean : } 9.19 \\
\text { SD : } 0.8\end{array}$ \\
\hline
\end{tabular}

\section{a. Forest plot}

Figure 4 shows that acupressure is effective in reducing labor pain. Pregnant women who received acupressure therapy expe- rienced labor pain 1.8 units lower than without acupressure $(\mathrm{SMD}=-1.83 ; 95 \% \mathrm{CI}=$ -2.37 to $-1.29 ; \mathrm{p}<0.001)$. 
Fitriana et al./ Accupressure on Hyperemesis Gravidarum and Birth Delivery Pain

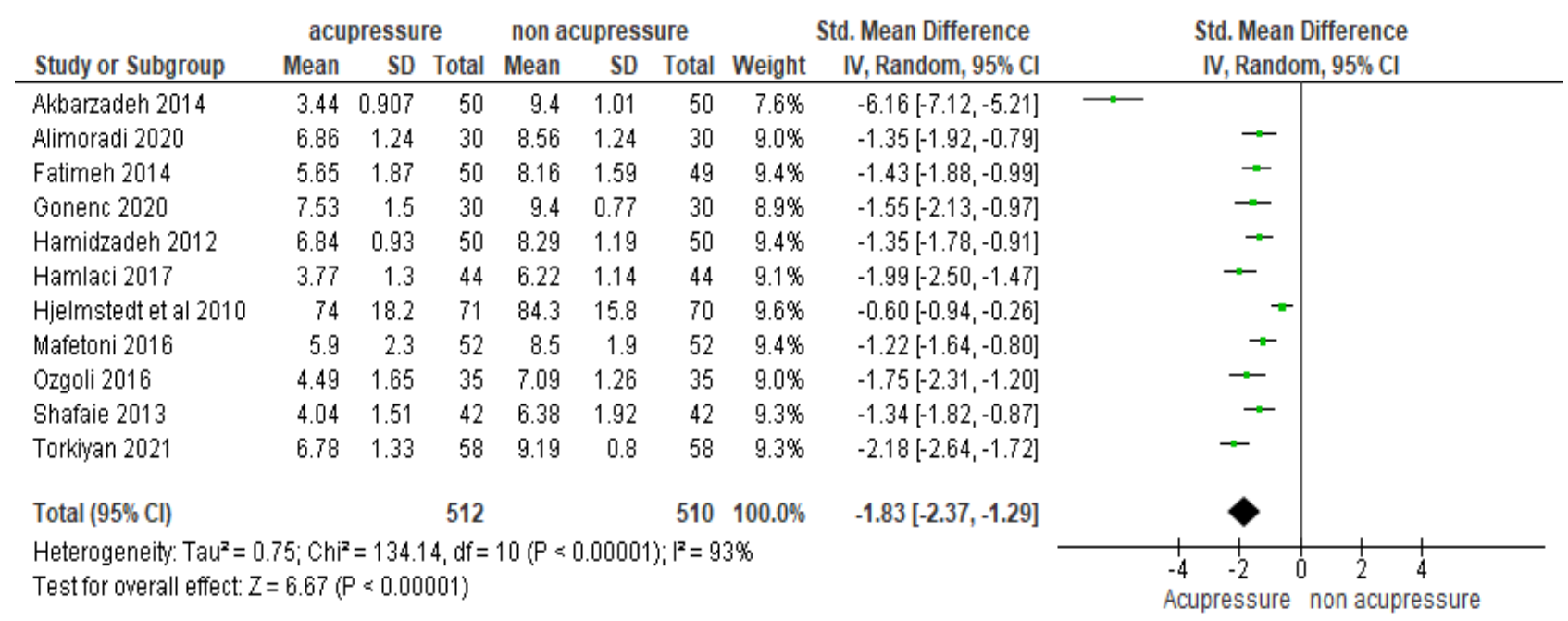

\section{Figure 4. Forest plot of the effect of acupressure on labor pain in laboring mothers}

\section{b. Funnel plot}

In Figure 5, the funnel plot graph of the effect of acupressure on labor pain in laboring women shows an asymmetric distribution of the primary study estimates which are more on the right than the left of the vertical line, thus identifying a slight publication bias towards reducing the actual effect (underestimate).

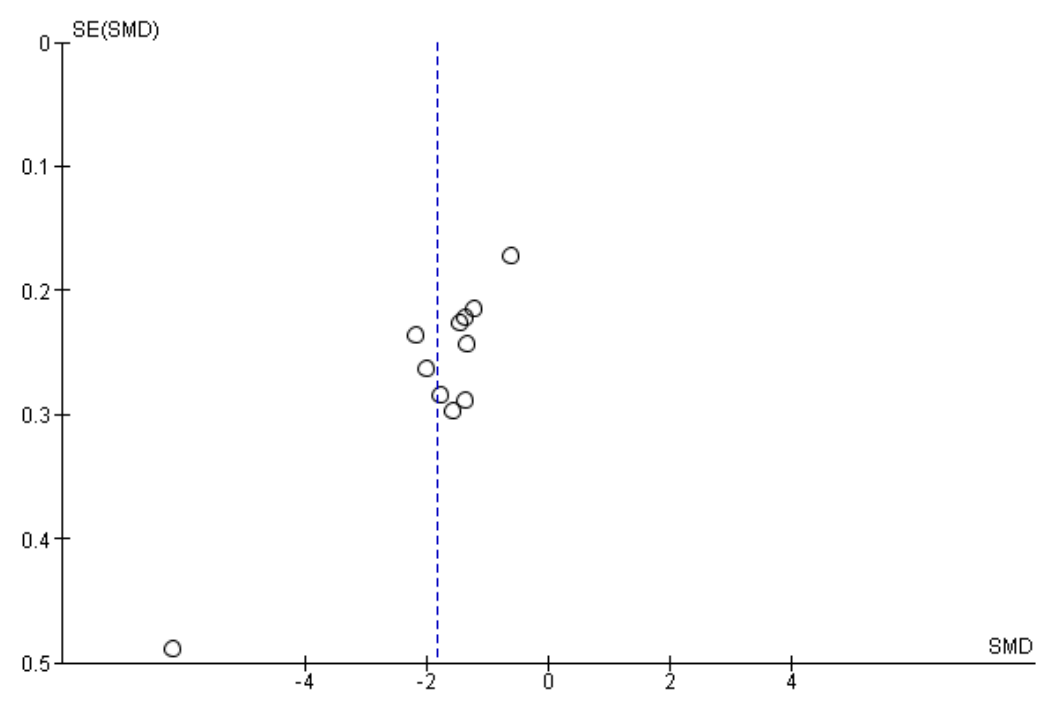

Figure 5. Funnel plot of the effect of acupressure on labor pain in laboring mothers

\section{DISCUSSION}

Acupressure is applying pressure to acupuncture points of the body using Pascal's principles and the principles of acupuncture. Acupressure can maintain and control the function of internal organs and balance yin and yang with dynamic circulation and stimulate the body's meridian pathways where vital energy flows (Shin, Song and Seo, 2007). Acupressure is a non-pharmacological method with minimal side effects and risks to the health of mothers and babies (Hamidzadeh et al., 2012). 
Several studies have been conducted to prove that acupressure can reduce the intensity of nausea and vomiting as well as labor pain, where pressure is applied to certain acupressure points such as the Pc6 point to reduce the severity of nausea and vomiting in pregnant women (Tara et al., 2020), as well as the LI4 point effective to reduce pain and duration of labor and mothers feel satisfied, and no side effects were found (Hamidzadeh et al., 2012).

This study uses a systematic review and meta-analysis study design with the aim of obtaining general conclusions as the basis for providing therapy/intervention from various similar studies that have been carried out by previous researchers who examined the provision of acupressure interventions for hyperemesis gravidarum and labor pain in pregnant women and childbirth in Indonesia in other countries.

Meta-analysis is an epidemiological study that combines and statistically combines data from primary research results that discuss the same hypothesis so as to obtain quantitative summary results (Egger and Smith in Murti, 2018). The results of the research are presented in the form of forest plots and funnel plots.

The forest plot is a diagram showing information from each of the studies studied and estimates of the overall results. It also shows visually the magnitude of variation (heterogeneity) between studies (Akobeng, 2005 in Murti, 2018).

A funnel plot is a diagram in a metaanalysis used to show possible publication bias in the trials identified and included in the meta-analysis (Sedgwick, 2013; Murti, 2018).

\section{Effect of acupressure on hyper- emesis gravidarum in pregnant women}

Giving acupressure therapy is effective in reducing hyperemesis gravidarum. Preg- nant women who received acupressure therapy experienced hyperemesis gravidarum 0.8 units lower than those without acupressure $(\mathrm{SMD}=-0.84 ; 95 \% \mathrm{CI}=-1.18$ to -0.5; $\mathrm{p}<0.001)$. The results of the study by Bulbul and Baser 2018 stated that giving acupressure at the PC6 acupuncture point with a bracelet did not completely eliminate nausea and vomiting caused by hyperemesis gravidarum but had a decreasing effect during certain periods of the day.

Another study by Gurkan and Arslan (2008) stated that acupressure is effective in controlling and reducing symptoms of nausea and vomiting during pregnancy. Juwita (2015) strengthens the literature review which states that the complementary nursing intervention of acupressure at the PC6 point can be categorized as an intervention that is safe and quite effective in reducing nausea and vomiting in pregnant women who do not receive other therapy besides acupressure.

Acupressure can maintain and control the function of internal organs and balance yin and yang by dynamic circulation of chi and retained blood by stimulating the meridian pathways in the body through which vital energy flows. Acupressure can also inhibit the function of the cerebral cortex through nerve stimulation (Shin, Song and Seo, 2007).

Acupressure at certain acupuncture points stimulates peripheral nerve endings which results in increased skin blood flow and blood microcirculation and stimulates the pituitary gland to form Beta-endorphins resulting in a decrease in $5 \mathrm{HT}_{3}$ ( 5 hydroxytryptamine type 3) as a messenger of nausea and vomiting to the nausea and vomiting center in the brain. Therefore, the message of nausea and vomiting is also inhibited so that nausea and vomiting are reduced (Alfira, 2017). 


\section{The Effect of Acupressure on Labor Pain in Maternity}

Giving acupressure therapy is effective in reducing labor pain. Pregnant women who received acupressure therapy experienced labor pain 1.8 units lower than without acupressure $(\mathrm{SMD}=-1.83 ; 95 \% \mathrm{CI}=-2.37$ to $-1.29 ; \mathrm{p}<0.001)$. In the study of Hajiamini et al., 2012 wrote that giving acupressure can significantly reduce pain intensity immediately after 30 minutes to 1 hour after the intervention, but in this study the decrease in pain intensity had a more persistent effect on the ice massage intervention.

However, in the study of Ozgoli et al., 2016 which examined the effect of acupressure at points $\mathrm{LI}_{4}$ and BL32 compared to usual care without acupressure to reduce labor pain, it was stated that acupressure at points LI4 and BL23 could significantly reduce labor pain than the control group in all study periods.

Acupressure has four basic effects on the body: analgesic, homeostasis, immune enhancement, and sedative/psychological medicine (Alimoradi et al., 2019). The painrelieving effect of acupressure has been described using the gate control theory of Melzack and Wall, 1965 which states that pain impulses can be regulated or inhibited by defense mechanisms along the central nervous system. Pain impulses are transmitted when the defenses are opened and pain impulses are inhibited when the defenses are closed and this is the basis for the theory for pain relief, where stimulation of acupressure points activates inhibitory neurons that block projection neurons to send pain impulses to the brain so that the gates of the gelatinous substance are closed and pain messages to the brain are blocked (Nature, 2020, Bahrudin, 2018).

The limitation of this research is that there is still publication, search and language bias. It is hoped that further meta-analysis research can conduct research using more databases and in various languages.

\section{AUTHOR CONTRIBUTION}

Alfira Fitriana is the main researcher who selects the topic, searches and collects research data. Agus Kristiyanto and Hanung Prasetya analyzed data and reviewed research documents.

\section{FUNDING AND SPONSORSHIP}

This study is self-funded.

\section{CONFLICT OF INTEREST}

There is no conflict of interest in this study.

\section{ACKNOWLEDGMENT}

We are very grateful to database providers PubMed, Science Direct, and Google Scholar.

LIST OF ABBREVIATIONS
HG = Hiperemesis Gravidarum
PICO= Population, Intervention, Compa-
rison/ Control, Outcome
RCT= Randomized Controlled Trials
PUQE= Pregnancy-Unique Quantification
of Emesis and Nausea
VAS= Visual Analogue Scale
RevMan= Review Manager
IASP = International Association for Study
of Pain
NVP= Nausea and Vomiting in Pregnancy
RINVR= Rhodes index of nausea, vomiting
and retching
5 HT3 $=5$ hydroxytryptamine type 3

\section{REFERENCES}

Alam H (2020). Upaya Mengurangi Nyeri Persalinan dengan Metode Akupresur (Efforts to Reduce Labor Pain with the Acupressure Method). Bandung: Media Sains. 
Fitriana et al./ Accupressure on Hyperemesis Gravidarum and Birth Delivery Pain

Alfira N (2017). Efek akupresur pada titik p6 dan st36 untuk mencegah post operative nausea and vomiting pada pasien laparatomi dengan spinal anastesi (The effect of acupressure at points p6 and st36 to prevent postoperative nausea and vomiting in laparotomy patients with spinal anesthesia). Makasar: UNHAS.

Alimoradi Z, Kazemi F, Valiani M dan Gorji $M$ (2020). Effects of ear and body acupressure on labor pain and duration of labor active phase: A randomized controlled trial. Complement ther med. 20(1): 766-774. https://doi.org/10.1016/j.ctim.2020.102413.

Bulbul T, Baser M (2018). The effect of acupressure applied to P6 acupuncture point on nausea, vomiting and retching. Asian Pac J Health Sci. 5(1): 146-149. https://doi.org/10.21276/apjhs.2018.5.1.32.

Gurkan O dan Arslan H (2008). Effect of acupressure on nausea and vomiting during pregnancy. Complement Ther Clin Pract. 14(1): 46-52. https://doi.org/10.1016/j.ctcp.2007.07.002.

Hajiamini, Z. et al. (2012) Comparing the effects of ice massage and acupressure on labor pain reduction. Complement Ther Clin Pract. 18(3): 169-172. https://doi.org/10.1016/j.ctcp.2012.0 5.003 .

Hamidzadeh A, Shahpourian F, Orak R, Montazeri A, Khosravi A (2012). Effects of $\mathrm{LI}_{4}$ acupressure on labor pain in the first stage of labor. $J$ Midwifery Womens Health. 57(2): 133-138. https://doi.org/10.1111/j.1542-2011.2011.00138.x.

Juwita (2015). Literature review: Terapi komplementer akupresur pada titik perikardium 6 dalam mengatasi mual dan muntah pada kehamilan (Literature review: Complementary acupres- sure therapy at pericardium point 6 in overcoming nausea and vomiting in pregnancy). Jurnal Ners Lentera. Retrieved from: http://journal.wima.ac.id/index.php/NERS/article/view/ 712 (Accessed: 17 December 2020).

Li G, Zeng J, Tian J, Levine MAH, Thabane L (2020). Multiple uses of forest plots in presenting analysis results in health research. J Clin Epidemiol. 117: 89-98. https://doi.org/10.1016/j.jclinepi.2019.09.021.

Mafetoni R, Shimo A (2016). The effects of acupressure on labor pains during child birth: Randomized clinical trial. Rev Lat Am Enferm. 24:e2738. https://doi.org/10.1590/1518-8345.0739.2738.

Mahmoudikohani F, Torkzahrani S, Saatchi K, Nasiri M (2019). Effects of acupressure on the childbirth satisfaction and experience of birth: A randomized controlled trial. J Bodyw Mov Ther. 23(4): 728-732. https://doi.org/10.1016/j.jbmt.2019.04.002.

Makowski D, Piraux F, Brun F (2019). From experimental network to metaanalysis methods and applications with $\mathrm{R}$ for agronomic and environmental sciences. France: Springer Nature B.V.

Martonffy A, Rindfleisch K, Lozeau A, Potter B (2012). First trimester complications. Prim Care. 39(1): 71-82. https://doi.org/10.1016/j.pop.2011.11. 004 .

Mobarakabadi S, Shahbazzadegan S, Ozgoli $G$ (2019). The effect of P6 acupressure on nausea and vomiting of pregnancy: A randomized, single-blind, placebocontrolled trial. Elsevier. 1-6 doi: https://doi.org/10.1016/j.aimed.2019 .07 .002 .

Murti B (2018). Prinsip dan metode riset epidemiologi (Epidemiological rese- 
Fitriana et al./ Accupressure on Hyperemesis Gravidarum and Birth Delivery Pain

arch principles and methods). edisi IV. Surakarta: Program Studi Ilmu Kesehatan Masyarakat, Program Pascasarjana, Universitas Sebelas Maret.

Ozgoli G, Mobarakabadi S, Heshmat R, Alavi M, Sheikhan Z (2016). Effect of LI4 and BL32 acupressure on labor pain and delivery outcome in the first stage of labor in primiparous women: A randomized controlled trial. Complement ther med. 29(0): 175-180. https://doi.org/10.1016/j.ctim.2016.1 0.009 .

Setyowati H (2018). Akupresur untuk kesehatan wanita berbasis hasil penelitian (Acupressure for women's health based on research). Magelang: Unimma Press.

Shin H, Song Y, Seo S (2007). Effect of neiguan point (P6) acupressure on ketonuria levels, nausea and vomiting in women with hyperemesis gravidarum. J Adv Nurs. 59(5): 510-519. https://doi.org/10.1111/j.1365-2648.2007.04342.x.

Tara F, Ghalandarabad M, Kargar Z, Azizi $\mathrm{H}$, Esmaily H (2020). The effect of acupressure on the severity of nausea, vomiting, and retching in pregnant women: A randomized controlled trial. J Complement Med. 27(4):252259. https://doi.org/10.1159/000505637.

Tulmac O, Kilic R, Yaman S, Aktulum F, Simsek G, Erdinc S (2021). Evaluation of the vestibular system with video head impulse test in pregnant women with hyperemesis gravidarum. J Obstet Gynaecol. 47(1): 96-102. https://doi.org/10.1111/jog.14433. 